\title{
Energy Balance Variation on the Snow Surface during the Snow Covered Season in the Norikura Highland, Japanese Alpine Area
}

\author{
Motoshi NISHIMURA $^{1 *}$, Akihiko SASAKI ${ }^{2}$ and Keisuke SUZUKI ${ }^{3}$ \\ 1 Interdisciplinary Graduate School of Science and TecPology, Department of Mountain and Environmental Science, Shinshu University \\ *17st402j@shinshu-u.ac.jp \\ 2 Department of Geography and Environmental Studies, Kokushikan University \\ 3 Faculty of Science, Environmental Sciences, Shinshu University
}

(Received May 30, 2018; Revised manuscript accepted November 16, 2018)

\begin{abstract}
In this study, the characteristics of snowmelt in the Norikura highland were investigated using an energy balance analysis to calculate the amount of snowmelt. Meteorological observations were conducted on the Norikura highland (1590 $\mathrm{m}$ a.s.l.) and an energy balance analysis was carried out on the snow surface during the snow cover seasons. The result showed that multi-year datasets of meteorological observations revealed characteristics such as low air temperature and vapor pressure, and weak wind speed. Throughout each season of snow cover averaged net radiation, the sensible heat flux and latent heat flux were $88.9 \%$, $16.4 \%$ and $-6.3 \%$ energy ratio to the total snowmelt energy, respectively. Each day, conditions were classified as rainy or non-rainy. The result for rainy conditions showed that net shortwave radiation decreased, while net longwave radiation increased greatly. Latent heat and sensible heat flux also increased. Although there was little precipitation heat flux, larger snowmelt energy was provided when it rained. In the late snowmelt period, the snowmelt rate calculated from the energy balance analysis was compared to the observed value, and the two were almost consistent.
\end{abstract}

Key words: snowmelt, energy balance, alpine area

\section{Introduction}

The interest in snowmelt and glacier ablation has increased recently as a result of increased air temperatures from climate change. Moreover, the onset of the snowmelt season is earlier and the period of snow cover is becoming shorter (Rixen et al., 2012). Without analysis of the physical processes between the atmosphere and snow surfaces, snow ablation and glacier mass balance cannot be determined. Modern meteorological instruments enable researchers to make highly sensitive observations involving the measurement of multiple meteorological parameters. With this background, many studies of snow and ice ablation have been reported at locations in the European Alps, the Himalayan Mountains, the Tibet highlands and New Zealand (e.g. Bintanja and van den Broeke, 1994; Oerlemans and Knap, 1998; Andreassen et al., 2008; van den Broeke et al., 2008; Datt et al., 2008; Giesen et al., 2009; Gillett and Cullen, 2011; Conway and Cullen, 2013; Cullen and Conway, 2015; Mattews et al., 2015; Lu et al., 2016).

It is necessary to consider the energy exchange between the atmosphere and the surface when discussing snowmelt or glacial mass balance because the energy exchange is based on heterogenous atmospheric conditions such as air temperature, wind direction and speed, and radiation intensity. However, these atmospheric conditions are sensitive to the geographical conditions and the season. The atmospheric circumstances and the difference in climate affect the surface energy balance (Sicart et al., 2008; Giesen et al., 2009). For instance, an energy balance analysis for the Koryto Glacier (Kamchatka Peninsula, Russia) and showed that the most effective energy for ablation is sensible heat flux (Konya et al., 2004). Another study showed that net radiation was responsible for $80 \%$ of the snowmelt in Niigata Prefecture in Japan (Matsumoto et al., 2010). These methods reveal the surface energy balance, and more accurately analyze snowmelt processes than other snow ablations methods such as the Degree-day method (Konya et al., 2004; Nishimura et al., 2019). In addition, Koike et al. (1993) showed that the ratio of the snowmelt energy source changed with altitude, topography, and season. Koike et al. (1993) and Suzuki et al. (2002) used limited meteorological components and obtained reasonable results for understanding the snowmelt process. However, as stated above, atmospheric conditions vary across a target area. To understand the snowmelt in an area, it is necessary to conduct multiple-component meteorological observations 
to understand the properties of the atmospheric conditions of a region and discuss the snowmelt process based on the actual measured values.

Snow cover is an important aspect of an alpine natural environment along with features such as geography and vegetation. The Japanese Alps is a heavy snowfall region of the world, where the winter snowfall is retained as a snow cover. The natural environment in an alpine area tends to be variable because the air temperature gradient with elevation is very steep. The snowmelt dynamics of alpine areas is an important factor that forms the environment, so it is necessary to understand the dynamics of the snowmelt process.

The meteorological observation network in the Japanese alpine areas is inadequate (Suzuki, 2012; Suzuki, 2013). The strong winter monsoon makes the atmospheric conditions in the Japanese alpine areas very severe, and maintaining observation devices is among the various difficulties. For example, installing a power source for devices and approaching the observation point. Although there has been much research on snowmelt in Japan, these efforts have mostly focused on low-elevation areas (e.g. Matsumoto et al., 2010). It is thought that the period of snow cover in high-elevation areas is longer than that in low-elevation areas (Beniston et al., 2003), and the snowmelt processes at high elevations in Japan remain unmeasured and unknown.

In this study, an energy balance analysis of the snow surface was conducted based on meteorological observations using equipment installed on the east-facing slope of Mt. Norikura at $1590 \mathrm{~m}$ a.s.l. This elevation corresponds to the subalpine zone in the Japanese Alps. Few studies have provided actual meteorological observations or discussed the snowmelt process using an energy balance analysis at elevations $>1000 \mathrm{~m}$ a.s.l. in Japan, and these studies were not conducted within the elevation zone targeted in this study. Considering that the variations in the surface energy balance are controlled by the climate and meteorological conditions, revealing the energy balance and understanding the snowmelt processes at this study site will be valuable. The results of this study can thus demonstrate how the characteristics of the meteorological conditions and surface energy balance in this environment affect the snowmelt process, and also provide information on the fundamental relationship between the surface energy balance and snowmelt globally.

\section{Site description}

Mt. Norikura is a generic term for a series of peaks located at the southern edge of the Northern Alps at the center of the main island (Honshu) in Japan. One of the highest peaks is Mt. Kengamine (3025 m a.s.l.). It is distinct from the east and west slopes of the Norikura highlands, which are covered in forests. A meteorological observation station is located at $1590 \mathrm{~m}$ a.s.l on the east face of
Mt. Norikura (Fig. 1), and is in the subalpine zone. In this area seasonal snow cover forms every winter. The study site is located on a flat area open to the sky; however, there is a coniferous forest surrounding (5-10 $\mathrm{m}$ away from) the site.

An automatic meteorological observation station (AWS) was installed in the Norikura highlands at $1590 \mathrm{~m}$ a.s.l. For this study, we examined only snow-cover periods from $2011 / 12$ to $2015 / 16$. The exception was 2014/15, when observations were prevented by instrument malfunction. The components were designed to measure and record; air temperature, relative humidity, net shortwave radiation, net longwave radiation, atmospheric pressure, wind speed and direction, and snow depth (Table 1). The specifications of each meteorological observation sensor are shown in Table 2. The data for each parameter were recorded every 10 minutes, except for snow depth, which was recorded every hour. Hourly data were made by averaging the data recorded every 10 minutes. This averaged dataset was applied in this study. Precipitation observations were not conducted at an AWS in the winter; therefore, for this study the precipitation data from the Precipitation Observed Station (POS in Fig. 1) at $1450 \mathrm{~m}$ a.s.l was used $(1.8 \mathrm{~km}$ from the AWS). Precipitation was observed using a tipping bucket rain gauge $(0.5 \mathrm{~mm}$ for one tip) with a heating system and a wind protector.

Meteorological observations were conducted at each height (Fig. 2) including those of air temperature and relative humidity (height from the ground: $4.8 \mathrm{~m}$ ), net shortwave and longwave radiation (height from the ground: $3.7 \mathrm{~m}$ ), and wind speed (height from the ground: $5.3 \mathrm{~m})$.

\section{Method}

\subsection{Data analysis}

We calculated and analyzed the energy balance on the flat snow surface at the AWS during the observation period. We conducted the energy balance analysis using the energy balance formula:

$$
Q_{M}=Q_{R}+Q_{H}+Q_{E}+Q_{P}
$$

where $Q_{M}$ is the energy flux used for melting, $Q_{R}$ is the net radiation, $Q_{H}$ is the sensible heat flux, $Q_{E}$ is the latent heat flux for condensation/evaporation and $Q_{P}$ is the precipitation heat flux by rain. The energy flux towards the surface from the atmosphere is defined as positive. However, when the snow surface temperature is negative, total energy, right side of equation (1), is consumed by heating of snowpack, so total energy is not equal to $Q_{M}$ and snowmelt is not occurred.

The energy from radiation was calculated using the following formulas:

$$
Q_{R}=R_{n e t}=S W_{n e t}+L W_{n e t}
$$




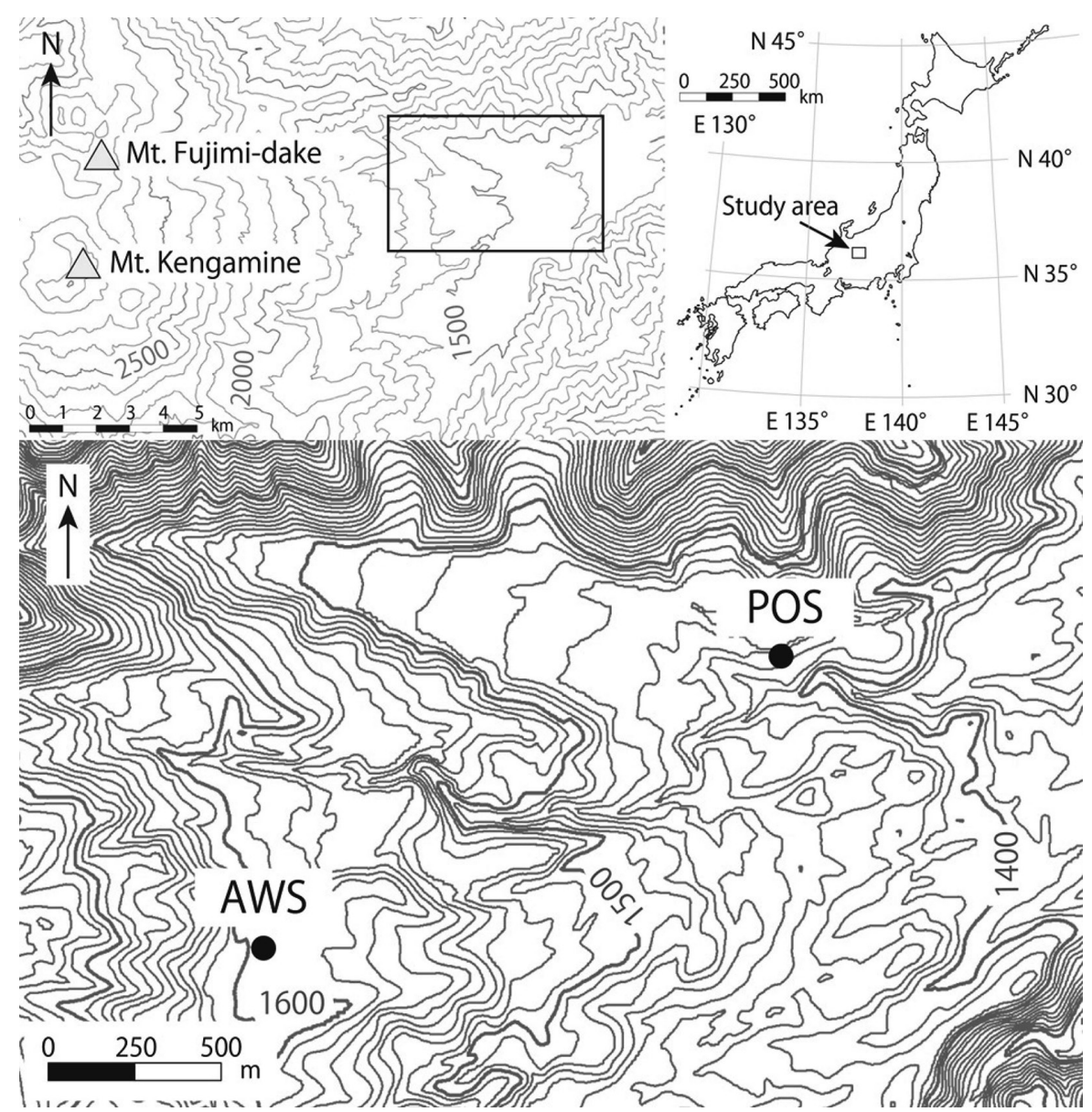

Fig. 1. Maps of the east slope of the Norikura highlands showing the AWS and POS stations and the surrounding topography.

Table 1. List of meteorological observation elements.

\begin{tabular}{|c|c|c|}
\hline Element & Abbreviation & dimension \\
\hline Air temperature & $T_{a}$ & ${ }^{\circ} \mathrm{C}$ \\
\hline Relative humidity & $r h$ & \\
\hline Wind speed & $U$ & $\mathrm{~m} \mathrm{~s}^{-1}$ \\
\hline Wind direction & $W D$ & degree \\
\hline Atmospheric pressure & $P$ & $\mathrm{hPa}$ \\
\hline incoming shortwave radiation & $S W \downarrow$ & $\mathrm{W} \mathrm{m}^{-2}$ \\
\hline outgoing shortwave radiation & $S W \uparrow$ & $\mathrm{W} \mathrm{m}^{-2}$ \\
\hline incoming longwave radiation & $L W \downarrow$ & $\mathrm{W} \mathrm{m}^{-2}$ \\
\hline outgoing longwave radiation & $L W \uparrow$ & $\mathrm{W} \mathrm{m}^{-2}$ \\
\hline Snow depth & $H$ & $\mathrm{~m}$ \\
\hline
\end{tabular}

$$
\begin{aligned}
& S W_{n e t}=S W \downarrow-S W \uparrow=S W \downarrow\left(1-\alpha_{\text {albedo }}\right) \\
& L W_{n e t}=L W \downarrow-L W \uparrow=L W \downarrow-\varepsilon \sigma T_{0}^{4}
\end{aligned}
$$

where $\alpha_{\text {albedo }}$ is the albedo of the surface and $Q_{R}$ is the energy of net radiation $\left(R_{n e t}\right)$. This is the sum of the incoming shortwave and longwave radiation ( $S W \downarrow$ and $L W \downarrow)$ and outgoing shortwave and longwave radiation ( $S W \uparrow$ and $L W \uparrow$ ) at the surface. Here, $\varepsilon$ is the emissivity of the surface, and is equal to unity, $\sigma$ is the StefanBoltzmann's constant $\left(\sigma=5.67 \times 10^{-8} \mathrm{~W} \mathrm{~m}^{-2} \mathrm{~K}^{-4}\right)$, and $T_{0}$
$(\mathrm{K})$ is the snow surface temperature. In this study, the Stefan-Boltzmann law was used along with $\varepsilon$ and $\sigma$, and the surface temperature was determined by $L W \uparrow$. When $T_{0}$ becomes positive, the observed $L W \uparrow$ is corrected so that $T_{0}$ is turned to be $273.2 \mathrm{~K}$.

The turbulent heat flux was calculated using a bulk aerodynamic approach:

$$
\begin{aligned}
& Q_{H}=\rho C_{p} C_{H} U\left(T_{a}-T_{0}\right) \\
& Q_{E}=\rho l C_{E} U(0.622 / P)\left(e-e_{0}\right)
\end{aligned}
$$

where $C_{H}$ and $C_{E}$ are the bulk exchange coefficients for the sensible heat and latent heat fluxes, respectively, and $\rho\left(\mathrm{kg} \mathrm{m}^{-3}\right)$ is the moist air density. $C_{p}\left(=1.004 \mathrm{~kJ} \mathrm{~K}^{-1} \mathrm{~kg}^{-1}\right)$ is the atmospheric specific heat at constant pressure, $U$ is the wind speed, $T_{a}$ is the air temperature, and $l\left(\mathrm{~J} \mathrm{~kg}^{-1}\right)$ is the latent heat of evaporation or sublimation. $P$ is the atmospheric pressure, $e$ is the water vapor pressure, and $e_{0}$ is the surface water vapor pressure. In this study, the energy balance analysis was conducted only during the period of snow cover, therefore, the surface is the same as the snow surface. Both bulk exchange coefficients for sensible heat and latent heat under neutral atmospheric conditions were given by Conway and Cullen (2013):

$$
C_{H}=C_{E}=\kappa^{2} /\left[\ln \left(z_{v} / z_{0 v}\right) \ln \left(z_{t} / z_{0 t}\right)\right]
$$


Table 2. List of meteorological observation components, sensor specifications, and accuracy at the AWS.

Observation Components

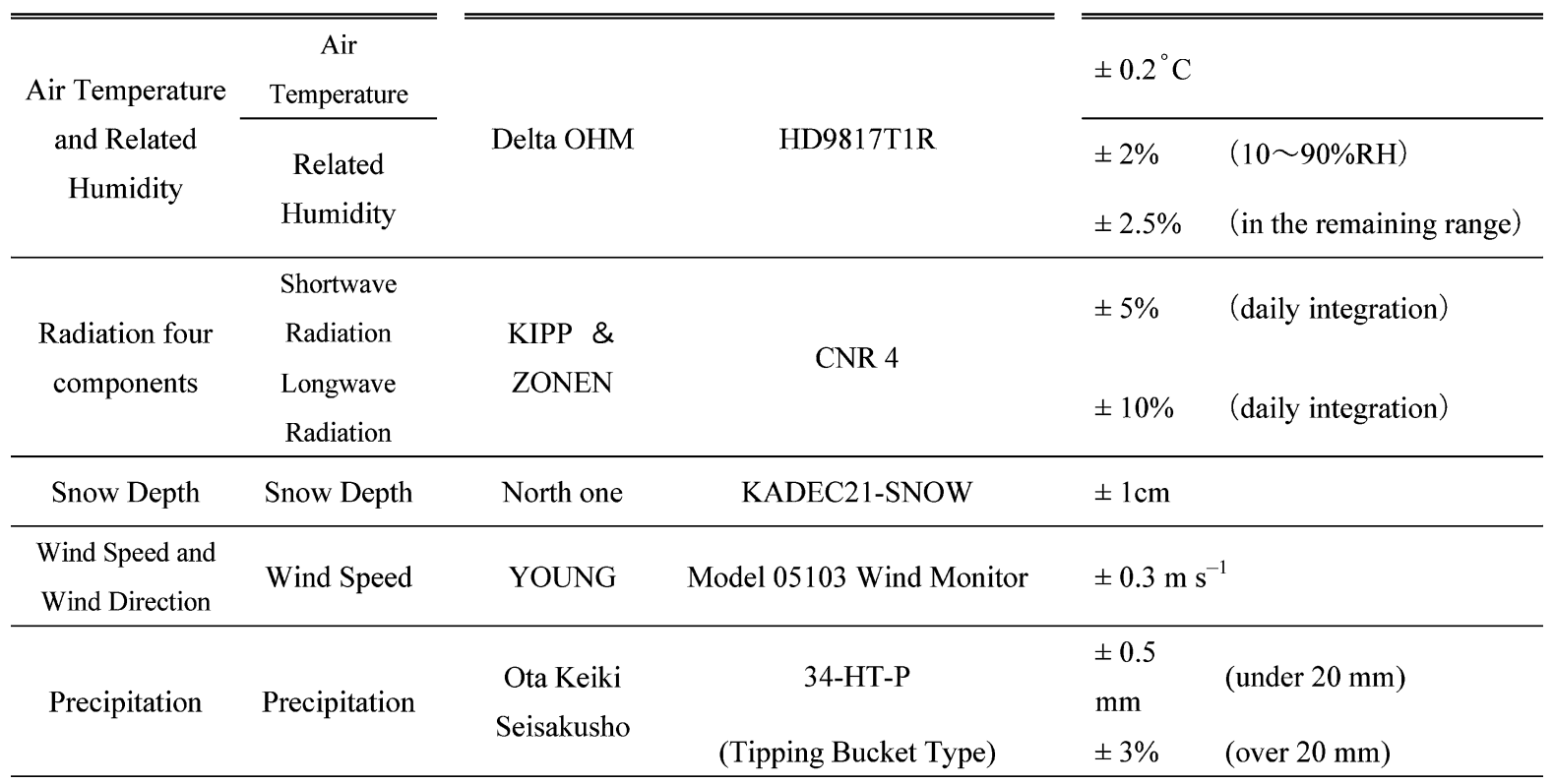

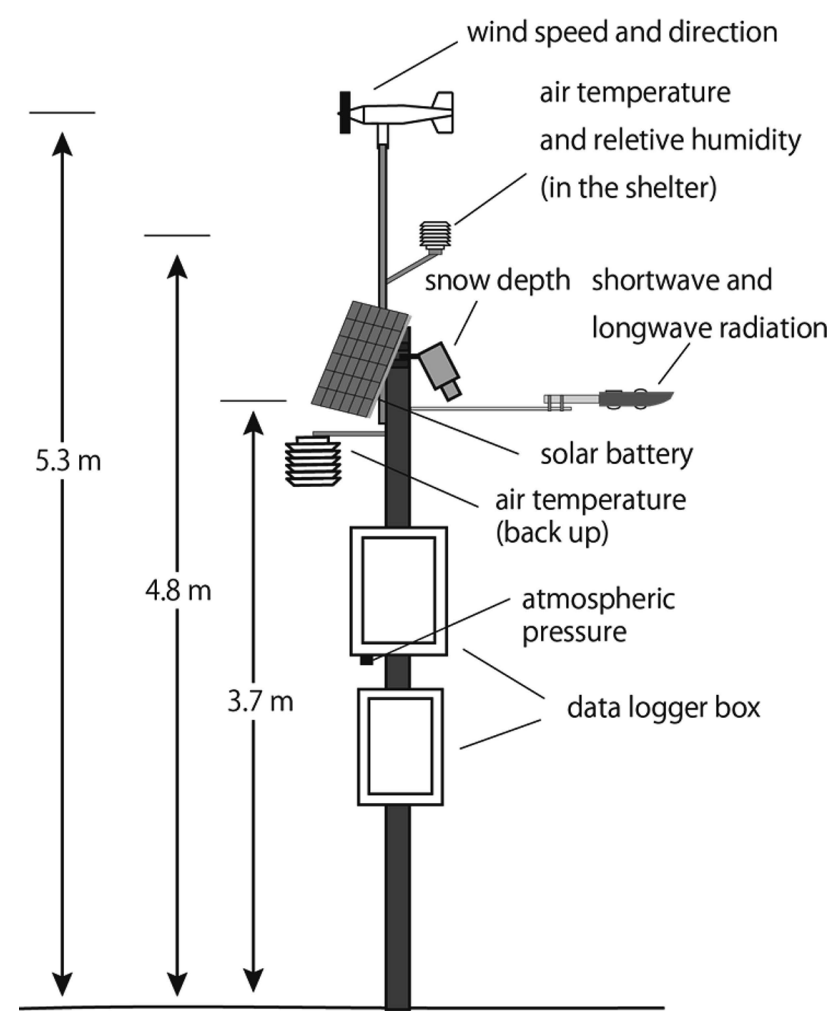

Fig. 2. Meteorological observation instruments.

Here, $\kappa(=0.4)$ is the von Kármán constant, $z_{v}(=5.3 \mathrm{~m})$ and $z_{t}(=4.8 \mathrm{~m})$ are the height of wind speed and air temperature measurements, respectively, and $z_{0 v}$ and $z_{0 t}$ are the roughness length for momentum and temperature, respectively. In this study, $z_{0 v}=0.0002 \mathrm{~m}$ and $z_{0 v}$ is equal to $z_{0 t}$, because there was no reliable method for estimating $z_{0 v}$ and $z_{0 t}$ using only a bulk aerodynamic method without an eddy correlation method. The bulk exchange coefficient essentially depends on atmospheric
Table 3. The periods of energy balance analysis. This study conducted energy balance analysis only during snow covered periods.

\begin{tabular}{ccccc} 
& $2011 / 12$ & $2012 / 13$ & $2013 / 14$ & $2015 / 16$ \\
\hline \hline observation period & 6 Dec. - 30 Apr. & 18 Nov. - 19 Apr. & 26 Nov. - 26 Apr. & 25 Nov. - 7 Apr. \\
\hline
\end{tabular}

stability; however, the surface roughness length and the friction velocity cannot be observed directly. Thus, in this study, a constant value $\left(1.6 \times 10^{-3}\right.$ no dimensional $)$ was substituted for the bulk exchange coefficient, which assumes that the atmospheric stability is neutral (e.g. Matsumoto et al., 2010).

The precipitation heat flux was calculated using the following formula:

$$
Q_{P}=\rho_{w} C_{w}\left(T_{w}-T_{0}\right) P_{r}
$$

where $\rho_{\mathrm{w}}\left(\mathrm{kg} \mathrm{m}^{-3}\right)$ is the density of the water, $C_{w}(=$ $4.21 \mathrm{~kJ} \mathrm{~K}^{-1} \mathrm{~kg}^{-1}$ ) is the specific heat capacity of the water, $T_{w}$ is the temperature of a rain drop, which is equal to $T_{a}$ in this study, and $P_{r}\left(\mathrm{~m} \mathrm{~s}^{-1}\right)$ is the amount of precipitation. The period of the energy balance analysis is shown in Table 3. On 2013/14, precipitation data was not obtained due to instrument malfunctions, and analysis of $Q_{P}$ was not conducted.

The observed melt rate was determined to validate the calculated melt rate in $2015 / 16$, by multiplying the snow density by the decrease in snow depth, shown by the following formula:

$$
M=d_{\text {snow }} \cdot \Delta H \cdot 1 / \rho_{w}
$$

where $M$ (m water equivalent: w.e.) is the melt rate, $d_{\text {snow }}$ $\left(\mathrm{kg} \mathrm{m}^{-3}\right)$ is the density of snow cover, and $\Delta H(\mathrm{~m})$ is the decrease in snow depth. When $M$ is negative, it is set to zero. Snow pit observations were conducted four times 
Table 4. The results of the measured snow density $\left(\mathrm{kg} \mathrm{m}^{-3}\right)$. Observations were conducted by digging the snow pit and measuring the snow density at 3-cm intervals from the snow surface to the bottom. The values in this table are obtained by averaging all the sample data from one survey.

15 Mar.-22 Mar. 23 Mar.-2 Apr. 3 Apr.-4 Apr. 5 Apr--7 Apr.

\begin{tabular}{|c|c|c|c|c|}
\hline snow density & 401 & 410 & 431 & 440 \\
\hline
\end{tabular}

(10 March, 23 March, 3 April and 5 April) in the winter of $2015 / 16$ to measure the weight of each $100 \mathrm{~cm}^{3}$ snow sample. These were conducted near the AWS at $3-\mathrm{cm}$ intervals and increasing depth. The results are shown in Table 4. These values were calculated by averaging all the sample density data. For the period when snow density was not measured, snow density data were interpolated using the latest observation data prior to that period.

\subsection{Data interpolation}

\subsubsection{Shortwave radiation}

In the case of shortwave radiation, there is data loss due to heavy snow. To compensate for this lost data, the incoming shortwave radiation was estimated from the outgoing shortwave radiation and snow surface albedo data, which is set to 0.9 assuming to just after snowfall.

\subsubsection{Longwave radiation}

In the same case of data loss, the incoming longwave radiation was interpolated using the Stefan-Boltzmann's law, with measured $T_{a}$ and calculated air emissivity $\left(\varepsilon_{c a l}\right)$ (Konzelmann et al., 1994). First, we quantified the measured air emissivity $\varepsilon_{\text {meas }}$ using measured incoming longwave radiation and air temperature with the following formula:

$$
\varepsilon_{\text {meas }}=L W \downarrow / \sigma T_{a}^{4}
$$

Brutsaert (1975) proposed the equation (11) describing $\varepsilon_{\text {cal }}$ using calculated $\varepsilon_{\text {meas }}$, vapor pressure and air temperature.

$$
\varepsilon_{c a l}=\alpha\left(e / T_{a}\right)^{1 / \beta}
$$

$\alpha$ and $\beta$ are the arbitrary constants. Each value and the correlation between the calculated and observed emissivities are shown in Table 5 . This is calculated by air temperature and $L W \downarrow$, as shown in Fig. 3. This equation was applied under clear-sky conditions by Brutsaert (1975); however, in the present study, data on the degree of cloudiness was not collected, and the correlation between the calculated and observed values were statistically significant. Therefore, equation (11) was applied for all weather conditions in this study.

\subsubsection{Precipitation}

Precipitation was not measured at the AWS in the winter season. Missing precipitation data was interpolated
Table 5. Values of $\alpha$ and $\beta$ (Brutsaert, 1975) for this study, and average observed and calculated air emissivities during the analytical period in each year.

\begin{tabular}{cccccc} 
& $2011 / 12$ & $2012 / 13$ & $2013 / 14$ & $2015 / 16$ \\
\hline \hline \multicolumn{2}{c}{$\alpha, \beta$} & $0.89,15.0$ & $0.88,13.2$ & $0.86,10.6$ & $0.84,8.50$ \\
\hline \multirow{2}{*}{$\begin{array}{c}\text { average } \\
\text { emissivity }\end{array}$} & observed & 0.90 & 0.89 & 0.88 & 0.88 \\
\cline { 2 - 6 } & calculated & 0.90 & 0.89 & 0.87 & 0.87 \\
\hline
\end{tabular}
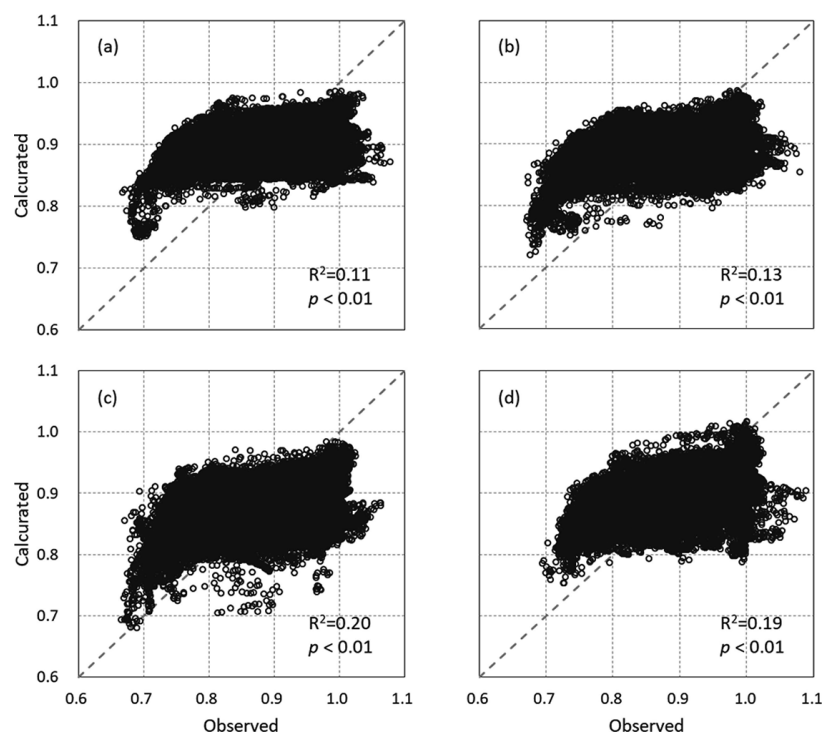

Fig. 3. Correlations between observed and calculated air emissivities in accordance with Brutsaert (1975).

from data collected at another precipitation observation station (POS in Fig. 1). The precipitation times determined from the precipitation data at POS, and it was assumed to be raining at the AWS at the same times. The air temperature threshold value was set to $1.7^{\circ} \mathrm{C}$ (Ogawa and Nogami, 1994) and the precipitation was classified as rain or snow.

\section{Result}

\subsection{Meteorological Observations}

The results of multi-year observations are shown in Table 6. The monthly mean air temperatures fluctuated between $-7.5^{\circ} \mathrm{C}$ to $4.4{ }^{\circ} \mathrm{C}$. Each year the mean monthly air temperature from December to March was below the freezing point and the monthly mean minimum air temperatures recorded in January were in the range of $-7.5^{\circ} \mathrm{C}$ to $-5.4{ }^{\circ} \mathrm{C}$. The daily mean air temperature in March was often below the freezing point. The monthly mean vapor pressure fluctuated in the observation period (2.8 to $6.7 \mathrm{hPa}$ ) and the minimum value was recorded in January. Most monthly mean wind speeds were found to be below $1.0 \mathrm{~m} \mathrm{~s}^{-1}$. The prevailing wind direction was from the South. The first day of continuous snow cover was different each year. The largest maximum annual snow depth was $2.04 \mathrm{~m}$ in 2013/14; conversely, the shallowest snow layer recorded was $0.96 \mathrm{~m}$ in 2015/16. Each snowmelt period continued from mid-February to 
Table 6. Monthly mean values of each meteorological element and mean values of the four seasons during the observation periods.

\begin{tabular}{|c|c|c|c|c|c|c|c|c|c|c|}
\hline \multirow{2}{*}{ year } & \multirow{2}{*}{ month } & $T_{a}$ & $U$ & \multicolumn{2}{|l|}{$W D$} & $R_{n e t}$ & \multirow{2}{*}{$\frac{S W_{n e t}}{\mathrm{~W} \mathrm{~m}^{-2}}$} & \multirow{2}{*}{$\frac{L W_{n e t}}{\mathrm{~W} \mathrm{~m}^{-2}}$} & \multirow{2}{*}{$\begin{array}{c}S W \downarrow \\
\mathrm{W} \mathrm{m}^{-2}\end{array}$} & \multirow{2}{*}{$\begin{array}{c}L W \downarrow \\
\mathrm{W} \mathrm{m}^{-2}\end{array}$} \\
\hline & & ${ }^{\circ} \mathrm{C}$ & $\mathrm{m} \mathrm{s}^{-1}$ & degree & $\mathrm{hPa}$ & $\mathrm{W} \mathrm{m}^{-2}$ & & & & \\
\hline 2011 & Dec. & -5.7 & 0.9 & 185 & 3.3 & 0.1 & 17.0 & -16.9 & 43.4 & 262.5 \\
\hline \multirow[t]{4}{*}{2012} & Jan. & -7.5 & 0.9 & 168 & 2.8 & -2.5 & 10.6 & -13.1 & 53.8 & 256.4 \\
\hline & Feb. & -6.8 & 0.9 & 168 & 3.1 & 8.1 & 21.5 & -13.4 & 77.1 & 260.2 \\
\hline & Mar. & -2.5 & 0.8 & 156 & 4.1 & 20.8 & 36.9 & -16.1 & 111.0 & 277.4 \\
\hline & Apr. & 2.5 & 0.6 & 169 & 5.6 & 64.7 & 79.9 & -15.2 & 153.5 & 296.7 \\
\hline \multirow[t]{2}{*}{2012} & Nov. & -1.1 & 0.8 & 149 & 4.6 & 7.7 & 32.1 & -24.4 & 55.2 & 273.0 \\
\hline & Dec. & -5.2 & 1.0 & 159 & 3.3 & -2.7 & 7.8 & -10.6 & 40.2 & 236.3 \\
\hline \multirow[t]{4}{*}{2013} & Jan. & -7.4 & 1.2 & 162 & 2.8 & 6.9 & 16.7 & -9.8 & 59.4 & 247.4 \\
\hline & Feb. & -6.5 & 1.2 & 181 & 3.0 & 4.8 & 18.2 & -13.5 & 79.2 & 215.3 \\
\hline & Mar. & -0.1 & 0.8 & 150 & 4.7 & 49.2 & 75.4 & -26.2 & 140.0 & 283.1 \\
\hline & Apr. & 2.4 & 0.9 & 165 & 5.1 & 87.0 & 108.1 & -21.0 & 184.3 & 278.6 \\
\hline \multirow[t]{2}{*}{2013} & Nov. & 0.1 & 0.7 & 137 & 4.2 & 5.5 & 13.5 & -7.9 & 45.0 & 282.6 \\
\hline & Dec. & -5.3 & 0.7 & 136 & 3.7 & -1.5 & 6.0 & -7.4 & 38.1 & 271.8 \\
\hline \multirow[t]{4}{*}{2014} & Jan. & -7.0 & 0.9 & 164 & 2.9 & 0.5 & 15.8 & -15.3 & 59.2 & 250.2 \\
\hline & Feb. & -6.3 & 0.9 & 148 & 3.0 & 12.7 & 34.4 & -21.7 & 97.0 & 249.2 \\
\hline & Mar. & -2.1 & 1.0 & 172 & 4.1 & 36.0 & 60.3 & -24.3 & 138.2 & 270.8 \\
\hline & Apr. & 2.7 & 0.7 & 142 & 4.8 & 80.8 & 112.4 & -31.6 & 194.2 & 279.6 \\
\hline \multirow[t]{2}{*}{2015} & Nov. & -1.4 & 0.7 & 128 & 5.1 & 6.5 & 21.6 & -15.1 & 46.2 & 285.2 \\
\hline & Dec. & -2.1 & 0.7 & 155 & 4.8 & 2.1 & 14.3 & -12.2 & 40.2 & 281.1 \\
\hline \multirow[t]{4}{*}{2016} & Jan. & -5.4 & 0.9 & 160 & 3.4 & 1.7 & 16.1 & -14.4 & 50.9 & 263.2 \\
\hline & Feb. & -5.4 & 0.8 & 164 & 3.5 & 10.9 & 28.3 & -17.5 & 78.9 & 258.8 \\
\hline & Mar. & -1.4 & 0.7 & 151 & 4.4 & 48.8 & 72.4 & -23.6 & 144.8 & 273.8 \\
\hline & Apr. & 4.4 & 0.6 & 189 & 6.7 & 73.2 & 88.5 & -15.3 & 136.5 & 305.4 \\
\hline \multirow{6}{*}{$\begin{array}{l}\text { monthly } \\
\text { mean value } \\
\text { in the } \\
\text { observation } \\
\text { period }\end{array}$} & Nov. & -0.8 & 0.7 & 138 & 4.6 & 5.0 & 21.1 & -16.1 & 47.5 & 275.8 \\
\hline & Dec. & -4.6 & 0.8 & 159 & 3.8 & -0.5 & 11.3 & -11.8 & 40.5 & 262.9 \\
\hline & Jan. & -6.9 & 1.0 & 164 & 3.0 & 1.6 & 14.8 & -13.1 & 55.8 & 254.3 \\
\hline & Feb. & -6.3 & 0.9 & 165 & 3.2 & 9.1 & 25.6 & -16.5 & 83.0 & 245.9 \\
\hline & Mar. & -1.5 & 0.8 & 157 & 4.3 & 38.7 & 61.3 & -22.5 & 133.5 & 276.3 \\
\hline & Apr. & 3.0 & 0.7 & 166 & 5.5 & 76.4 & 97.2 & -20.8 & 167.1 & 290.1 \\
\hline
\end{tabular}

early April and snow cover disappeared in April.

Inter-seasonal fluctuations of net shortwave and longwave radiation are shown in Fig. 4. The monthly mean net radiation and net shortwave radiation obtained their minimum values in December or January (Table 6). However, net longwave radiation did not show significant fluctuations in the observation period. Incoming shortwave radiation increased after December and the fluctuation of net shortwave radiation and net radiation showed the same trend as the incoming shortwave radiation. Net longwave radiation showed negative values throughout the observation period.

\subsection{Energy balance analysis}

The ratio of snowmelt energy in April to the total snowmelt energy was in the range 49 to $64 \%$ (Fig. 5). Every year, there was a small amount of snowmelt energy during the accumulation period (November to February), the average values for that period were in the range of 10.5 (November) to 14.4 (February) $\mathrm{W} \mathrm{m}^{-2}$. Snowmelt energy, in particular net radiation, increased gradually after February. According to Fig. 5, it is clear that snowmelt occurred with increasing snowmelt energy, whereas the sensible heat flux and latent heat flux did not show obvious increasing trends. Although the sensible heat flux shows large variation and its absolute value is relatively small, the positive heat flux during mid-winter, and on many days in the snowmelt period, results in an increase in the snowmelt energy. Conversely, the latent heat flux is mostly negative and does not show inter-seasonal variation during the period of snow cover. The absolute value is larger than that of the sensible heat flux. Therefore, the latent heat flux is shown to have a cooling effect on the snow cover. The ratio of each contributing source of melt energy to the total snowmelt energy is shown in Table 7. It is clear that the largest snowmelt energy source was the net radiation, which contributed $88.9 \%$. The net shortwave radiation contributed $>140 \%$, and the net longwave radiation contributed $<-50 \%$ of the melt energy. Sensible heat flux contributed $16.4 \%$, and the latent heat $-6.3 \%$. The precipitation heat flux did not substantially contribute to snowmelt because its ratio to 

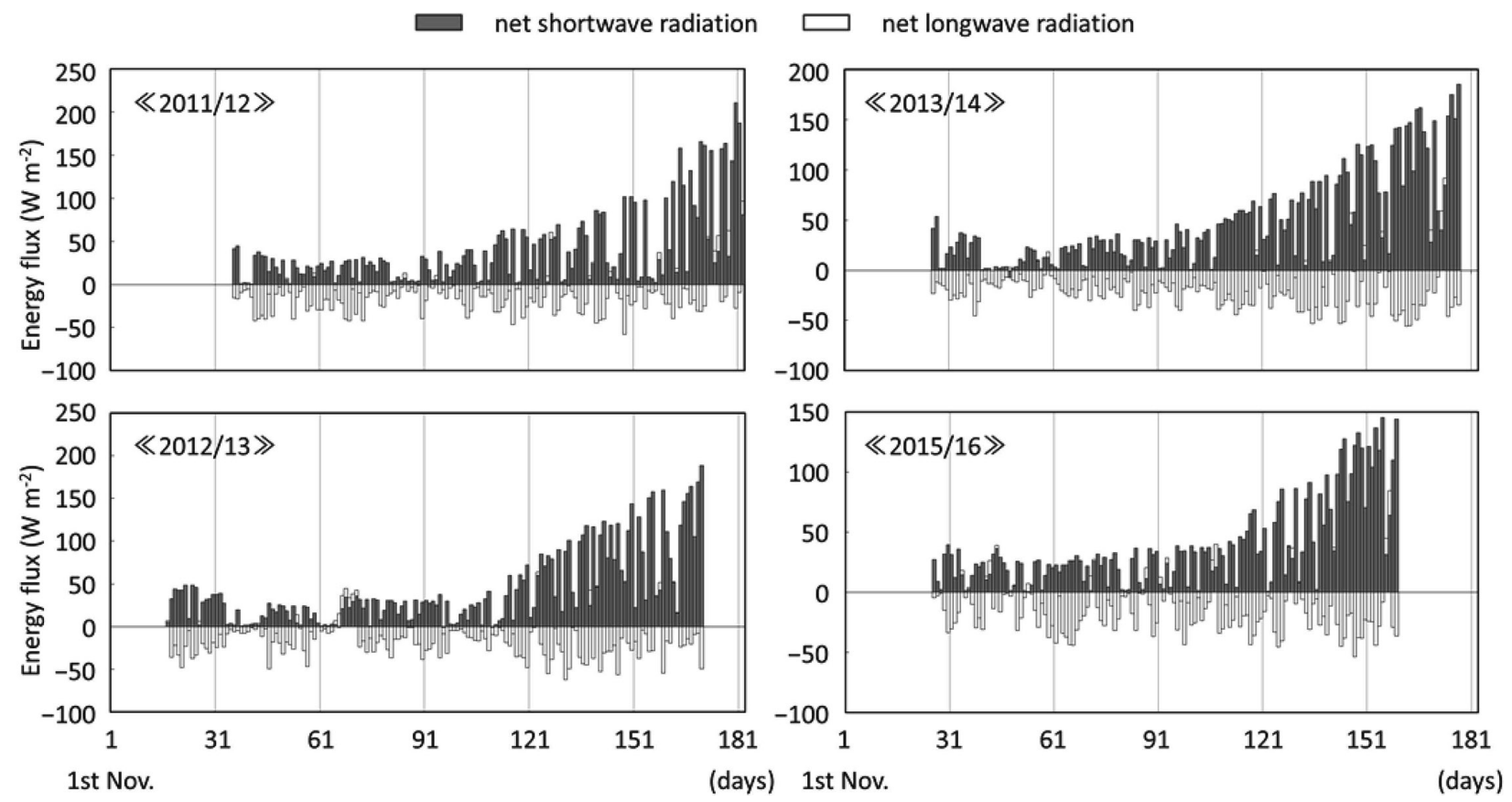

Fig. 4. Inter-seasonal fluctuation of net shortwave and longwave radiation.

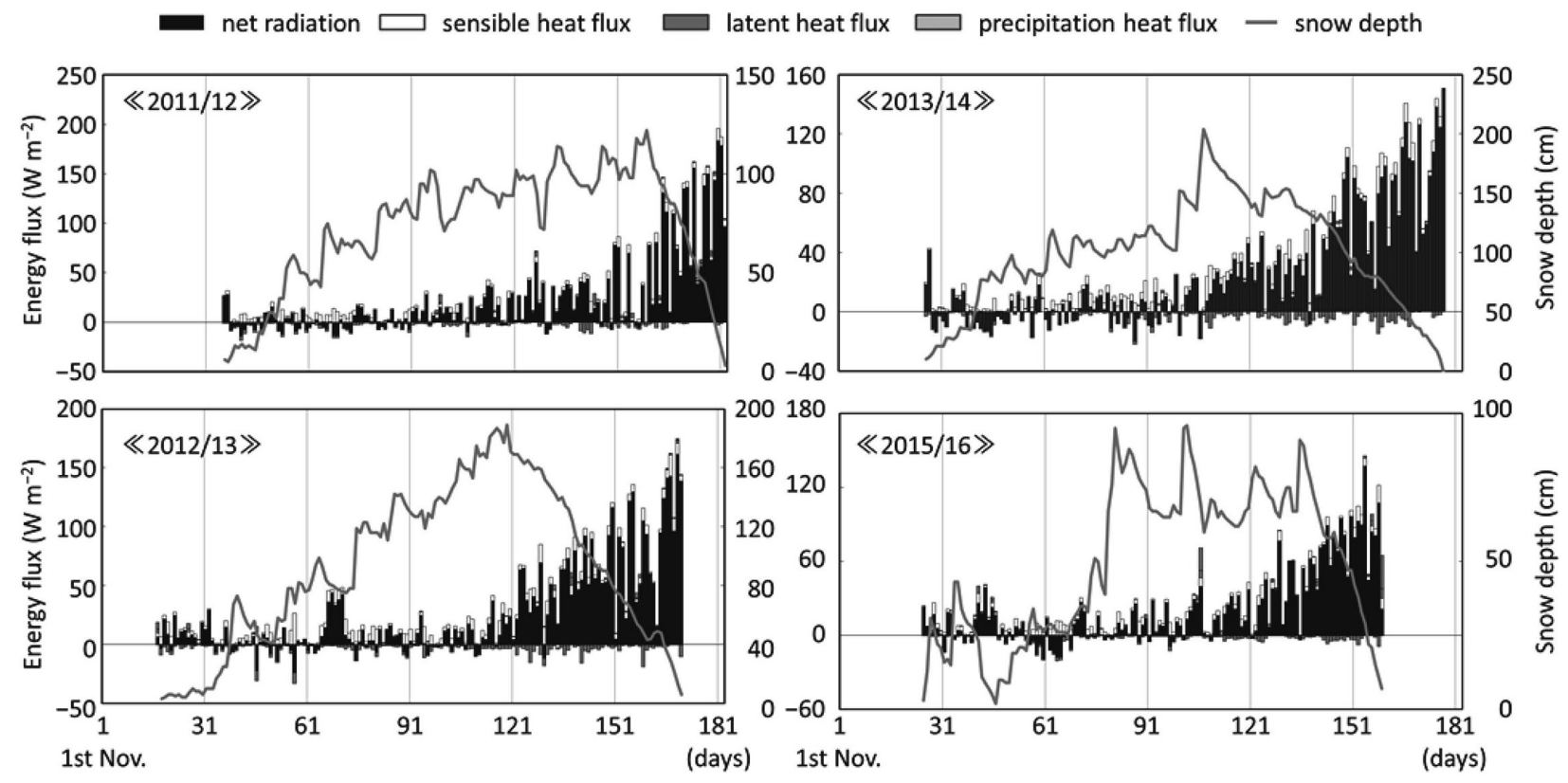

Fig. 5. Results of the energy balance analysis and the variations in the snow depth. The energy elements are the daily mean values and the snow depth is the daily maximum value.

the other heat fluxes was much smaller. Moreover, no yearly significant difference was seen in the heat flux.

In this study, rainy conditions were defined as the times that it was raining at the meteorological observation site. Every day and hour was classified as either nonrainy or rainy. The factors that had an impact on the energy balance at the snow surface under each condition were quantified. Table 8 shows the ratio of the number of hours of rain and snowmelt energy flux for each condition. Although rainy hours accounted for about $3 \%$ of the period, the amount of energy flux during rainy conditions was $4.0-6.9 \%$. Table 9 shows the hourly mean energy flux in cases of rainy and non-rainy conditions. The hourly mean net shortwave radiation under nonrainy conditions is approximately $40 \mathrm{~W} \mathrm{~m}^{-2}$ and under rainy conditions is $15.2-19.8 \mathrm{~W} \mathrm{~m}^{-2}$. Therefore, the net shortwave radiation decreased under rainy conditions. In contrast, the hourly mean net longwave radiation under rainy conditions was $33.3 \mathrm{~W} \mathrm{~m}^{-2}$ greater than that under the non-rainy conditions in the three-year average. Net turbulent fluxes under rainy conditions were greater than that in non-rainy conditions. The latent heat flux under rainy conditions was also $5.1 \mathrm{~W} \mathrm{~m}^{-2}$ larger than that for non-rainy conditions. Thus, there is a difference in the 
Table 7. The ratio of each snowmelt energy to the total snowmelt energy (\%).

\begin{tabular}{|c|c|c|c|c|c|}
\hline & & $2011 / 12$ & $2012 / 13$ & $2013 / 14$ & $2015 / 16$ \\
\hline \multirow{3}{*}{$R_{n e t}$} & $S W_{\text {net }}$ & 149.6 & 147.8 & 166.1 & 151.8 \\
\hline & $L W_{\text {net }}$ & -59.1 & -58.7 & -76.1 & -65.6 \\
\hline & $R_{n e t}$ & 90.5 & 89.1 & 90.1 & 86.0 \\
\hline \multicolumn{2}{|r|}{$Q_{H}$} & 14.6 & 18.0 & 17.3 & 15.6 \\
\hline \multicolumn{2}{|r|}{$Q_{E}$} & -6.3 & -7.9 & -7.4 & -3.5 \\
\hline \multicolumn{2}{|r|}{$Q_{P}$} & 1.3 & 0.8 & N.D. & 1.9 \\
\hline
\end{tabular}

Table 8. The ratio of the number of hours (\%) during the entire analysis period (upper lines) and the ratio of snowmelt energy flux $\left(\mathrm{W} \mathrm{m}^{-2}\right)$ to the total snowmelt energy flux (lower lines) for the entire study period, in rainy and non-rainy conditions, respectively.

\begin{tabular}{rcrrrr} 
& & $2011 / 12$ & $2012 / 13$ & $2013 / 14$ & $2015 / 16$ \\
\hline \hline \multirow{2}{*}{ hours } & non-rainy & 96.9 & 97.5 & N.D. & 97.1 \\
\cline { 2 - 6 } & rainy & 3.1 & 2.5 & N.D. & 2.9 \\
\hline \multirow{2}{*}{$\begin{array}{r}\text { snowmelt } \\
\text { energy flux }\end{array}$} & non-rainy & 93.5 & 96.0 & N.D. & 93.1 \\
\cline { 2 - 6 } & rainy & 6.5 & 4.0 & N.D. & 6.9 \\
\hline
\end{tabular}

Table 9. Hourly mean energy fluxes under rainy and non-rainy conditions $\left(\mathrm{W} \mathrm{m}^{-2}\right)$. Numbers in parentheses show the standard deviation for each energy component.

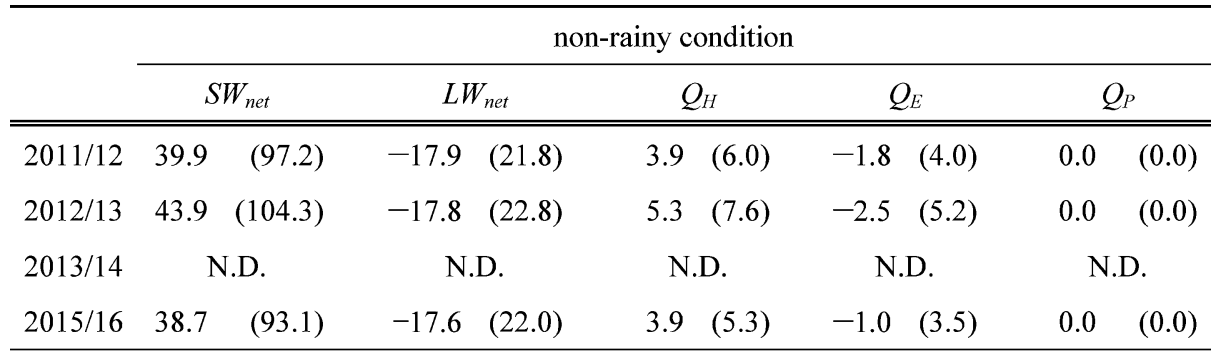

\begin{tabular}{|c|c|c|c|c|c|c|}
\hline & \multicolumn{6}{|c|}{ iny condition } \\
\hline & & $V_{n e t}$ & $L W_{\text {net }}$ & $Q_{H}$ & $Q_{E}$ & $Q_{P}$ \\
\hline $2011 / 12$ & 19.8 & (37.4) & 16.2 & $2.3 \quad(3.9)$ & $1.9 \quad(3.9)$ & $10.5 \quad(13.2)$ \\
\hline $2012 / 13$ & 18.6 & $(36.4)$ & 11.2 & $5.2 \quad(4.3)$ & $3.8 \quad(4.1)$ & $7.5 \quad(6.4)$ \\
\hline 2013/14 & & D. & N.D. & N.D. & N.D. & N.D. \\
\hline $2015 / 16$ & 15.2 & (24.7) & 19.1 & $4.2 \quad(4.8)$ & $4.2 \quad(5.5)$ & 16.9 \\
\hline
\end{tabular}

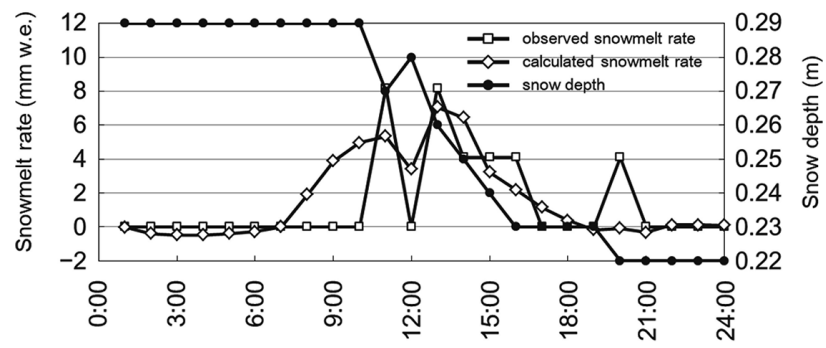

Fig. 6. Hourly calculated and observed snow melt rates and variations in the snow depth on April 2, 2016.

energy flux between rainy and non-rainy conditions.

\subsection{Comparison to the observed snowmelt rate}

In this study, the calculated snowmelt rate was compared to the observed snowmelt rate. The observed snowmelt rate was measured using snow density and the decrease in snow depth. This method was applied in the later snowmelt period because there was less variation of snow density and increasing snow depth at this point. The application period was thus from March 15 to April 7, 2016.

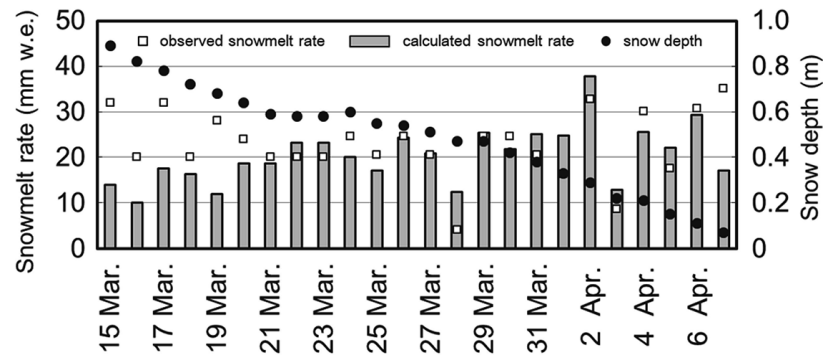

Fig. 7. Daily calculated and observed snowmelt rates and variations in snow depth in the later snowmelt period from March 15 to April 7, 2016.

Snow pit observations were conducted several times in the winter of 2015/16 to measure snow density. The observed date and the results are shown in Table 4. In the period during which snow density was not measured, missing data was interpolated using the results from the last observation. Hourly calculated and observed snowmelt rates and variations of snow depth for April 2, 2016 are shown in Fig. 6. Hourly observed snowmelt rates and calculated snowmelt rates for 2016 were integrated to obtain that of the later snowmelt period and 
calculate daily snowmelt rates, the results of which are shown in Fig. 7. The total amount of snowmelt observed was $552 \mathrm{~mm}$ w.e. (water equivalent) and the calculated snowmelt was $490 \mathrm{~mm}$ w.e. The observed snowmelt rate increased with time and the mean snowmelt rate was $23 \mathrm{~mm}$ w.e. per day. The two snowmelt rates were slightly different early in the period of their application; however, the variations in snowmelt rates were mostly corresponding.

\section{Discussion}

\subsection{Meteorological observation}

During the study period, the following meteorological properties existed at the study site: low air temperature, low vapor pressure, and weak wind speed. Low air temperature and low vapor pressure are representative meteorological features of alpine environments. In alpine areas $>1000 \mathrm{~m}$ a.s.l., the atmospheric characteristics, typically consist of low air temperature, low vapor pressure, low atmospheric pressure, and high wind speed. Under such a typical alpine environment, the heat capacity of the air and latent heat flux also are diminished due to low atmospheric pressure (Sicart et al., 2008; Verburg and Antenucci, 2010). In addition, the energy input from incoming shortwave radiation tends to increase with increasing altitude because the scatter and absorption of solar radiation is reduced (Verburg and Antenucci, 2010).

Meteorological observations in this study almost correspond to typical atmospheric conditions in alpine areas without a wind speed. The air temperature showed inter-seasonal variations: the coldest month was January and after that, the air temperature increased gradually with time. The mean temperature in January was $-6.9{ }^{\circ} \mathrm{C}$. A positive monthly mean temperature appeared only in April, suggesting that the daily mean temperatures on many days during the observation period were negative. The saturated vapor pressure depends on the air temperature. Thus, vapor pressure depends not only on the relative humidity but also on the air temperature. At low air temperatures, the vapor pressure often becomes low. The weak wind speed is caused by the coniferous forest surrounding the meteorological observation site. Although this observation site is open to the sky and the ground is flat, coniferous trees around the site provide a wind break and lower the wind speeds.

Net shortwave radiation increased with time during the observation periods. The fluctuation of net radiation depends on the budget of incoming and outgoing radiation. Therefore, two factors could affect the increasing net shortwave radiation. First, incoming shortwave radiation could increase with increase in the solar altitude. Second, the reflected shortwave radiation could decrease due to lower reflectance from the snow surface. The solar altitude becomes lowest at the winter solstice and begins to increase after that, and the reflectance of the snow surface decreases as snow metamorphism occurs (Warren, 1982). Generally, snow surface reflectance decreased because of the dirt (Conway et al., 1996), such as black carbon (BC) and atmospheric aerosol, on snow surface (e.g. Motoyoshi et al., 2005; Aoki et al., 2006). Although this study did not conducted a survey quantifying $\mathrm{BC}$ and aerosol, the metamorphism of snow grains was observed in snow pits. Therefore, the increase of the solar altitude and metamorphism of snow influenced shortwave radiation and resulted in increasing net shortwave radiation.

Net longwave radiation did not show an obvious inter-seasonal fluctuation. Incoming longwave radiation largely depends on the air temperature and the emissivity of the atmosphere. Conway et al. (2014) mentioned that vapor pressure, cloudiness, and the presence of aerosols in the atmosphere all affect the emissivity of the atmosphere. These factors possibly increase the incoming longwave radiation. In this study, the method of Konzelmann et al. (1994) was applied to calculate the emissivity of the atmosphere, which is considered in the air temperature and vapor pressure analyses. The variations in incoming longwave radiation did not show clear inter-seasonal differences. Outgoing longwave radiation depends on fluctuation of the snow surface temperature. The fluctuation range was not large. Because the fluctuation of incoming and outgoing longwave radiation was small, the inter-seasonal net longwave radiation did not show significant fluctuations.

Important factors for surface energy balance in alpine areas are air temperature, vapor pressure, atmospheric pressure, and incoming shortwave radiation. These conditions are infrequently reported in Japan; that air temperature will not be positive until March and dry air was observed like Norikura highland, and makes the snowpack cold under those conditions (detailed state is below). A detailed comparison with atmospheric conditions at low-elevation sites was conducted in this study. However, this study revealed the meteorological conditions in the Norikura highlands, which consists of typical alpine atmospheric conditions.

\subsection{Energy balance analysis \\ 5.2.1 Energy balance properties}

Each year, the highest snowmelt frequently occurred in the later snowmelt period (March and April). This is because the net shortwave radiation, which has the largest effect on snowmelt at this site, is highest during that period. The snowmelt energy sources that increased later in the snowmelt periods included not only net radiation but also turbulent heat fluxes. This is because the air temperature and vapor pressure increased with time (after January), suggesting that the sensible and latent heat fluxes were increasing.

\subsubsection{The ratio of each energy flux}

The yearly difference in the property of snow 
surface energy flux is not easily understood. The results of the energy balance analysis were similar for each year, and the largest energy source was net radiation, which controlled the snowmelt at this site. Net turbulent heat fluxes were negative because the latent heat flux term was itself very negative. The precipitation heat flux accounted for a small percentage of the total energy for snowmelt. One of the meteorological properties to consider is low air temperature. The sensible heat flux and latent heat flux contribute relatively little to the snowmelt than does the net radiation. In particular, latent heat flux was seen to be negative. It can be assumed that the low air temperature resulted in a decrease in vapor pressure, which caused snow sublimation to increase. This results in a negative heat exchange and in cooling of the snow surface.

Net radiation accounted for about $88.9 \%$ of the total melt energy. This is because weak wind speed and low air temperature decreased the turbulent heat flux. A large amount of the net radiation was shortwave radiation which was in a ratio $>140 \%$ and $<-50 \%$ to the net longwave radiation. This result reveals that net shortwave radiation contributed the highest to snowmelt at this site. The main snowmelt period was March and April at this site because of the low air temperature. Monthly mean air temperatures remained negative until April. Therefore, the sensible heat flux could not increase. However, incoming shortwave radiation increased with time in the observation period. Hence, more snowmelt energy was supplied by net radiation than by turbulent heat flux. In addition, later in the snowmelt periods, increase in the solar altitude and decrease in the snow surface albedo accelerated the increase in net radiation on the snow surface.

Air temperature and vapor pressure in 2015/16 were higher than those for the other years; however, the sensible heat flux was lower than those in 2012/13 and 2013/14. The latent heat flux in 2015/16 was the lowest of the four years. Turbulent heat flux depends on the air temperature, vapor pressure and wind speed. Although there was high air temperature and vapor pressure in $2015 / 16$, the turbulent heat flux was low. This is because the wind speed in 2015/16 was weaker than that in other years.

Air temperature is a factor representative of snowmelt, and it can be used as a substitute when considering the spatial amount of snowmelt, or the mass balance of glacier ablation. A temperature index method (for example the degree-day method) is widely used in cases where meteorological observations are hard to obtain because monitoring equipment is hard to install in the study area. This is because air temperature is closely related to several factors of snowmelt energy. Increasing air temperature seems to lead to increasingly turbulent heat flux, and increasing air temperature can result from increased shortwave radiation. Nevertheless, the results of this study indicate that the most effective energy source for snowmelt is net radiation. Matsumoto et al. (2010) conducted an energy balance analysis at Oshirakawa (Niigata Prefecture, Japan), which is located at a lower altitude, and recorded higher air temperatures than those at this observation site. They reported that net radiation accounted for $80.3 \%$, while sensible heat flux, latent heat flux, and precipitation heat flux account for $16.2 \%, 3.0 \%$, and $0.5 \%$, respectively. Sicart et al. (2008) compared climate, altitude, and latitude at three sites using energy balance analysis. These sites were located in Northern Sweden ( $67^{\circ} 55^{\prime} \mathrm{N}, 1370 \mathrm{~m}$ a.s.l.), the French Alps ( $45^{\circ} 00^{\prime} \mathrm{N}$, $2760 \mathrm{~m}$ a.s.l.) and the Bolivian Andes (16 $15^{\prime} \mathrm{S}, 5050 \mathrm{~m}$ a.s.l.). They showed that net radiation accounted for $55 \%$ in Northern Sweden and accounted for approximately $84 \%$ (French Alps) and over 100\% (Bolovian Andes). In the sites at the Bolivian Andes and the French Alps, the net radiation controlled surface energy balance. This is because the latent heat flux affected the energy sink from sublimation, which was caused by the fact that the atmosphere was very dry due to high elevation. In contrast, the energy balance at the site in Northern Sweden showed a different property: high contribution of turbulent energy flux. This is why this site is located at a high-latitude glacier and in a maritime climate zone. These regional characteristics of the maritime climate affect small shortwave radiation due to low sun elevation and high air temperature and humidity. In addition to these results, Konya et al. (2004) showed results similar to those of Northern Sweden in Sicart et al. (2008). According to their energy balance analysis at the Koryto Glacier in the Kamchatka Peninsula in the summer of 2000 , net radiation accounted for $33 \%$, sensible heat flux for $44 \%$, and latent heat flux for $23 \%$ of total melt energy. This result reflects the effect of high air temperatures in summer. Cullen and Conway (2015) showed that net radiation accounted for $64 \%$, sensible heat flux for $23 \%$ and latent heat flux for $11 \%$ of the total melt energy at Brewster Glacier, southern New Zealand. The relatively small energy flux of the net radiation at the Brewster Glacier seems to be why the Brewster Glacier is located in temperate, maritime conditions. Therefore, the amplitude of the seasonal cycle of air temperature is small and makes turbulent energy flux large.

In this manner, the net radiation generally accounted for a large amount of melt energy in several areas; however, Giesen et al. (2009) showed the results of a comparison between some glaciers located between the $50^{\circ}$ and $70^{\circ}$ latitudes on both hemispheres. The results of the report indicate that the difference in snowmelt period, altitude, or climate of an observation site results in a variation in the melt energy balance, but no simple dependencies of the absolute or relative energy fluxes on latitude, altitude, air temperature or wind speed could be found. In this study, where the meteorological properties of the site led to low air temperature, low vapor pressure, and weak wind speed; the energy balance properties: net 
radiation, sensible heat flux, and latent heat flux, accounted for about $88.9 \%, 16.4 \%$, and $-6.3 \%$, respectively. This result revealed the characteristics of the melt energy balance under typical alpine climate conditions of low temperature and low vapor pressure.

\subsubsection{Comparison to rainy condition and non-rainy condition}

The comparison between the snow surface energy balance under rainy and non-rainy conditions revealed the difference in the surface energy balance due to local weather conditions in alpine regions. Precipitation type is generally determined by air temperature. In low air temperature regions such as the high latitudes and high elevations, winter precipitation occurs as snowfall in many cases and gets preserved as snow cover. However, if winter precipitation falls as rain, the snow cover is decreased and snowmelt will be drained. This is an important factor influencing alpine snowmelt.

The temperature that determined whether precipitation would be rain or snow was $1.7^{\circ} \mathrm{C}$ (Ogawa and Nogami, 1994). According to this metric and the precipitation data, hours were classified as either rainy or nonrainy. This classification showed that almost $3 \%$ of the observation period was rainy hours.

By classifying the weather conditions, the differences in melt energy could be discovered. Net shortwave radiation decreased under rainy conditions; in contrast, net longwave radiation increased. As a result, the net radiation increased each year: $164 \%$ in $2011 / 12,114 \%$ in $2012 / 13$, and $163 \%$ in 2015/16. The sensible and latent heat fluxes almost increased. Although Table 8 shows the ratio of rainy hours to total hours to be almost $3 \%$, the ratio of snowmelt energy during the rainy periods accounted for 4.0-6.9\%. This suggests that more snowmelt energy was available at the snow surface under rainy conditions than under non-rainy conditions.

Under rainy conditions, less net shortwave radiation and more net longwave radiation was observed, and more turbulent heat flux was calculated than in non-rainy periods. When it rains, the sky is covered with clouds and much of this cloudiness obstructs incoming shortwave radiation. In addition, the extensive cloudiness strengthened the incoming longwave radiation because cloudy skies emit more longwave radiation. The higher vapor pressure and air temperature enhanced emissivity of the atmosphere during the periods with rainy conditions (Marks et al., 1998). Sensible heat flux increased a little under rainy conditions because under these conditions air temperatures were generally higher. The latent heat flux was much greater under rainy conditions than under nonrainy conditions. Under rainy conditions, vapor pressure increased. Therefore, the atmospheric and snow surface vapor pressures became larger. Positive latent heat flux also became larger, suggesting that vapor frequently condensed on the snow surface, and thus more condensation heat flux was provided to the snow surface. This is likely the reason more latent heat flux is supplied during rainy conditions.

\subsubsection{Comparison to the observed snowmelt rate}

Figure 6 shows daily variations in the observed and calculated snowmelt rates. The calculated snowmelt rate showed negative values at night and positive values in the daytime. The cold content of the snowpack was cancelled by the energy supply during the daytime. As shown in Fig. 6, between 0:00 and 7:00, the snowmelt rates (calculated by the energy balance analysis) were negative. The snowpack was cooling during that period. Then after 7:00, the cold content of snowpack was cancelled by absorbing energy and snowmelt occurred.

During this study, a large number of daily snowmelt rates were accumulated from March 15 to April 7, 2016 (Fig. 7). This period, during the later snowmelt period, was selected because the variability of the snow density was assumed to be small at this time. Additionally there was little increase in the snow depth during this period. This paper cannot provide ground energy flux and conductive heat flux data regarding the snow cover because continuous observations of the snow temperature profile was not conducted in this study. Therefore, the conductive heat flux was regarded as zero because we considered the snow temperature to be $0^{\circ} \mathrm{C}$ in the later snowmelt period. The two total snowmelt rates were compared, the calculated snowmelt was underestimated at $62 \mathrm{~mm}$ w.e., which mostly agreed with the measured rate. The method for measuring the snowmelt rate was simple and easy to validate using only snow density and snow depth. However, snow density must be observed frequently, and although using the density of dry snow is ideal, this study used wet snow density. There is a possibility that the observed snowmelt rate is over (or under) estimated against the effective snowmelt rate and these problems offer room for improvement in the future.

While the underestimation of the calculated snowmelt was seen early in the snowmelt period, overestimation was seen in the later snowmelt period. In the early snowmelt period, snowmelt water stored in the snowpack may have been refreezing due to negative latent heat flux. The analysis in this study was conducted with under an assumption that there is little conductive heat flux in the snowpack. This possibly was the reason for the difference in the snowmelt rates in the early snowmelt period. Kojima and Motoyama (1985) showed that snowmelt occurred at a rate of $1 \mathrm{~mm}$ w.e. per day as a result of ground heat flux at the Mosiri (Hokkaido, Japan), except for times immediately after continuous snow cover formed. Taking this assumption and these results into consideration, the difference between the observed and calculated snowmelt rates can be explained. These results were validated and found to be reasonable. 


\section{Conclusion}

In this study, energy balance analysis was conducted on the snow surface at the Norikura highland $(1590 \mathrm{~m}$ a.s.l.) during the seasons with snow cover. This revealed inter-seasonal variation of the energy sources that cause snowmelt and the properties of the energy balance during the periods of snow cover.

The results showed that several meteorological factors, including low air temperature, low vapor pressure, and low wind speed, had important effects on the energy balance. Based on these meteorological observations, an energy balance analysis was conducted. The energy balance analysis indicated that the most effective energy flux for snowmelt was the net radiation (88.9\%). The second most effective was the sensible heat flux (16.4\%). The third was precipitation heat flux, which contributed almost $1.3 \%$ to the total energy of the snow melt. The latent heat flux had a negative contribution (-6.3\%) and was the smallest energy flux. This property, the energy sink due to the negative latent heat flux, cannot be observed frequently in low elevation regions of Japan and is typical of high elevation regions because of the dry atmosphere of these regions. This is why the low air temperature and the low vapor pressure made the turbulent heat flux small, resulting in an increase in the ratio of net radiation.

The properties of energy balance under rainy and non-rainy conditions were revealed by classifying the weather conditions. When it rained, net shortwave radiation decreased by $40-50 \%$; in contrast, net longwave radiation increased. Therefore, net radiation increased overall. Latent heat flux increased by $5.1 \mathrm{~W} \mathrm{~m}^{-2}$. Precipitation heat flux hardly contributed to the snowmelt.

On comparing of the observed and calculated snowmelt rates, the differences in their accumulative amount of snowmelt was found to be $62 \mathrm{~mm}$ w.e. This difference is believed to be accounted for by energy fluxes not applied in this study; therefore, the validity of this study was confirmed.

\section{Acknowledgments}

We appreciate the assistance of $\mathrm{T}$. Matsumoto of Niigata University for providing much advice on the methods of analysis. In addition, the BGR editor and two reviewers gave a lot of valuable comments and indication. Thanks to them, this paper was improved. We received many suggestions and useful opinions from members of our laboratory and they also helped us with the measurements. We express our gratitude to all of them.

\section{References}

Andreassen, L.M., van den Broeke, M.R., Giesen, R.H. and Oerlemans, J. (2008): A 5 year record of surface energy and mass balance from the ablation zone of Storbreen, Norway. J. Glaciol., 54, 245-258, doi: 10.3189/002214308784886199.

Aoki, T., Motoyoshi, H., Kodama, Y., Yasunari, T.J., Sugiura, K. and Kobayashi, H. (2006): Atmospheric aerosol deposition on snow surfaces and its effect on albedo. Scientific Online Letters on the Atmosphere (SOLA), 2, 13-16, doi:102151/ sola.2006-004

Beniston, M., Keller, F. and Goyette, S. (2003): Snow pack in the Swiss Alps under changing climatic conditions: an empirical approach for climate impacts studies. Theor. Appl. Climatol., 74, 19-31, doi: 10.1007/s00704-002-0709-1.

Bintanja, R. and van den Broeke, M.R. (1994): The Surface Energy Balance of Antarctic Snow and Blue Ice. J. Appl. Meteorol., 34, 902-926.

Brutsaert, W. (1975): On a drivable formula for long-wave radiation from clear skies. Water Resour. Res., 11, 742-744, doi: 10.1029/WR011i005p00742.

Conway, H., Gades, A. and Raymond, C.F. (1996): Albedo of dirty snow during conditions of melt. Water Resour. Res., 32, 1713-1718, doi: 10.1029/96wr00712.

Conway, J.P. and Cullen, N.J. (2013): Constraining turbulent heat flux parameterization over temperate maritime glacier in New Zealand. Ann. Glaciol., 54 (63), 41-51, doi:10.3189/2013 AoG63A604.

Conway, J.P., Cullen, N.J., Spronken-Smith, R.A. and Fitzsimons, S.J. (2014): All-sky radiation over a glacier surface in the Southern Alps of New Zealand: characterizing cloud effects on incoming shortwave, longwave and net radiation. Int. J. Climatol., 35, 699-713, doi: 10.1002/joc.4014.

Cullen, N.J. and Conway, J.P. (2015): A 22 month record of surface meteorology and energy balance from the ablation zone of Brewster Glacier, New Zealand. J. Glaciol., 61, 931946, doi: 10.3189/2015JoG15J004.

Datt, P., Srivastava, P.K., Negi, P.S. and Satyawali, P.K. (2008): Surface energy balance of seasonal snow cover for snowmelt estimation in N-W Himalaya. J. Earth Syst. Sci., 117, 567-573, doi: 10.1007/s12040-008-0053-7.

Giesen, R.H., Andreassen, L.M., van den Broeke, M.R. and Oerlemans, J. (2009): Comparison of the meteorology and surface energy balance at Storbreen and Midtdalsbreen, two glaciers in southern Norway. Cryosphere, 3, 57-74, doi: 10.5194/tc-3-57-2009.

Gillett, S. and Cullen, N.J. (2011): Atmospheric controls on summer ablation over Brewster Glacier, New Zealand. Int. J. Climatol., 31, 2033-2048, doi: 10.1002/joc.2216.

Koike, M., Koike, T. and Goto, I. (1993): Comparative research on the temporal and spatial distribution of energy budget on the snow surface using snowmelt models (in Japanese). Proc. Hydraul. Eng., 37, 147-152, doi: 10.2208/prohe.37.147.

Kojima, K. and Motoyama, H. (1985): Melting and heat exchange at the bottom of a snow cover. Ann. Glaciol., 6, 276-277, doi: 10.3189/1985AoG6-1-276-277.

Konya, K., Matsumoto, T. and Naruse, R. (2004): Surface heat balance and spatially distributed ablation modelling at Koryto glacier, Kamuchatka peninsula, Russia. Geogr. Ann., 86 A, 337-348, doi: 10.1111/j.0435-3676.2004.00236.x.

Konzelmann, T., van de Wal, R.S.W., Greuell, W., Bintanja, R., Henneken, E.A.C. and Abe-Ouchi, A. (1994): Parameterization of global and longwave incoming radiation for the Greenland ice sheet. Glob. Planet. Chang., 9, 143-164, doi:10.1016/09218181 (94) 90013-2.

Lu, H., Wei, W.S., Liu, M.Z., Han, X., Li, M. and Hong, W. (2016): Variations in seasonal snow surface energy exchange during a snowmelt period: an example from the Tianshan Mountains, China. Meteorol. Appl., 23, 14-25, doi:10.1002/ met.1511.

Marks, D., Kimball, J., Tingey, D. and Link, T. (1998): The sensitivity of snowmelt processes to climate conditions and forest cover during rain-on-snow: a case study of the 1996 Pacific Northwest flood. Hydrol. Processes, 12, 1569-1587, doi: 10.1002/(SICI)1099-1085(199808/09)12:10/11<1569::AIDHYP682>3.0.CO;2-L. 
Matsumoto, T., Kawashima, K., Togari-Ohta, A. and Shimamura, M. (2010): Estimation of outflow from the bottom of a snowpack using a combination of a temperature-radiation index model and a percolation model (in Japanese). J. Jpn. Soc. Snow and Ice (Seppyo), 72, 255-270.

Mattews, T., Hodgkins, R., Guðmundsson, S., Pálsson, F. and Björnsson, H. (2015): Inter-decadal variability in potential glacier surface melt energy at Vestari Hagafellsjökull (Langjökull, Iceland) and the role of synoptic circulation. Int. J. Climatol., 35, 3041-3057, doi:10.1002/joc.4191.

Motoyoshi, H., Aoki, T., Hori, M., Abe, O. and Mochizuki, S. (2005) Possible effect of anthropogenic aerosol deposition on snow albedo reduction at Shinjo, Japan. J. Meteorol. Soc. Jpn., 83A, 137-148, doi: 10.2151/jmsj.83a.137.

Nishimura, M., Sasaki, A. and Suzuki, K. (2019): Long-term fluctuation, modelling and prediction of the snow accumulation and ablation process in Norikura highland: Study using an energy balance analysis and ablation models (in Japanese). $J$. Geography (Chigaku Zassi), (in press).

Ogawa, M. and Nogami, M. (1994): Precipitation amount separated by precipitation type using discriminating temperature during winter season (in Japanese). J. Japan Society of Hydrol. and Water Resour., 7, 421-427, doi: 10.3178/jishwr.7.421.

Oerlemans, J. and Knap, W.H. (1998): A 1 year record of global radiation and albedo in the ablation zone of Morteratschgletscher, Switzerland. J. Glaciol., 44, 231-238, doi:10.3189/ S0022143000002574.

Rixen, C., Dawes, M.A., Wipf, S. and Hagedorn, F. (2012):
Evidence of enhanced freezing damage in treeline plants during six years of $\mathrm{CO}_{2}$ enrichment and soil warming. Oikos, 121, 1532-1543, doi: 10.1111/j.1600-0706.2011.20031.x.

Sicart, J.E., Hock, R. and Six, D. (2008): Glacier melt, air temperature, and energy balance in different climates: The Bolivian Tropics, the French Alps, and northern Sweden. J. Geophys. Res.: Atmos., 113, D24113, doi:10.1029/2008JD010406.

Suzuki, K. (2012) Snow hydrological study in the mountainous area and associated problems of meteorological observation (in Japanese). J. Japanese Assoc. of Hydrol. Sciences, 42, 109118, doi: $10.4145 /$ jahs. 42.109 .

Suzuki, K. (2013) Importance of Meteorological Observation in the Japanese Alps Region (in Japanese). J. Geography (Chigaku Zassi), 122 (4), 553-570, doi: 10.5026/jgeography.122.553.

Suzuki, K., Kameda, T., KoPo, M., Nakazawa, F., Uetake, J. and Fujii, Y. (2002): Meteorological observations on Sofiyskiy Glacier, Russian Altai Mountains. Polar meteorol. and glaciol., 16, 140-148.

van den Broeke, M., Smeets, P., Ettema, J. and Munneke, P.K. (2008): Surface radiation balance in the ablation zone of the west Greenland ice sheet. J. Geophys. Res., 113, D13105, doi: 10.1029/2007JD009283.

Verburg, P. and Antenucci, P.J. (2010): Persistent unstable atmospheric boundary layer enhances sensible and latent heat loss in a tropical great lake: Lake Tanganyika. J. Geophys. Res.: Atmos., 115, D11109, doi: 10.1029/2009JD012839.

Warren, S.G. (1982): Optical Properties of Snow. Rev. Geophys. Space Phys., 20, 67-89, doi:10.1029/rg020i001p00067. 